\title{
A NEW SPECIES OF SISYRINCHIUM SUBG. SISYRINCHIUM (IRIDACEAE) FROM MEXICO
}

\author{
Guy L. Nesom \& Luis Hernández S.
}

Department of Botany, University of Texas, Austin, Texas 78713 U.S.A.

\section{ABSTRACT}

Sisyrinchium novoleonense is described from Nuevo León and Coahuila, México, where it is abundant in areas of relatively high elevation around Cerro Potosí, Peña Nevada, and Sierra de Arteaga. It is a member of subg. Sisyrinchium and apparently related to the S. scabrum species group, but it clearly stands apart from these plants in its long rhizomes, large flowers with a long filament tube, and habitats at higher elevations. Based on records in LL,TEX, five other species of subg. Sisyrinchium are known from Coahuila, Nuevo León, and Tamaulipas: $S$. biforme, S. micranthum, S. dimorphum, S. demissum, and S. scabrum. The latter two probably are the closest relatives of $S$. novoleonense but they are more similar between themselves than is either to $S$. novoleonense.

KEY WORDS: Sisyrinchium, Iridaceae, México

\section{RESUMEN}

Se describe Sisyrinchium novoleonense de Nuevo León y Coahuila, México, abundante en areas que sobrepasan los 2700 metros de altitud del Cerro Potosí, Peña Nevada, y Sierra de Arteaga. La nueva especie pertenece al subg. Sisyrinchium y aparentemente esta relacionada con el grupo de especies de $S$. scabrum, sin embargo difiere claramente de esta por el mayor tamaño de rizoma, flor, y tubo estaminal y su habitat en elevaciones mayores. Con base en registros en LL,TEX, se conocen cinco especies mas del subg. Sisyrinchium de Coahuila, Nuevo León, y Tamaulipas: S. biforme, S. micranthum, S. dimorphum, S. demissum, y S. scabrum. Aunque los dos últimos son probablemente los mas cercanos a $S$. novoleonense, presentan mayor similitud entre sí que cualquiera de ellos con $S$. novoleonense. 


\section{PALABRAS CLAVE: Sisyrinchium, Iridaceae, México}

Recent studies have contributed greatly to an understanding of the phylogeny and taxonomy of Sisyrinchium L. and its close relatives (Rudall et al. 1986; Goldblatt et al. 1989 and 1990; Goldblatt 1990). Sisyrinchium is one of the largest genera within the tribe Sisyrinchieae Baker as well as the whole family, and the genus is well known for seemingly small and variable differences among some of its species. Each of four relatively recent papers (Oliver 1969; Calderón \& Rzedowski 1985; McVaugh 1989; Henrich \& Goldblatt 1987) has described a new species of Sisyrinchium from México, and there are now ca. 32 Mexican species (depending on concepts of species delimitation), seven in subg. Sisyrinchium and 25 in subg. Echthronema (Herbert) Goldbl. (sometimes treated as the genus Hydastylus Salisb.). Three recent treatments have clarified the taxonomy of the genus in the southern half of México, where more than two-thirds of the Mexican species occur (Henrich \& Goldblatt 1987; McVaugh 1989; Calderón \& Rzedowski 1990). In the course of an attempt to identify the Sisyrinchium of northeastern México, particularly in relation to several floristic surveys in progress within the area, it has become evident that the following species of sect. Sisyrinchium is undescribed.

Sisyrinchium novoleonense Nesom \& L. Hernández S., sp. nov. TYPE: MEXICO. Nuevo León: Mpio. Dr. Arroyo, Peña Nevada area, ca. 35 km

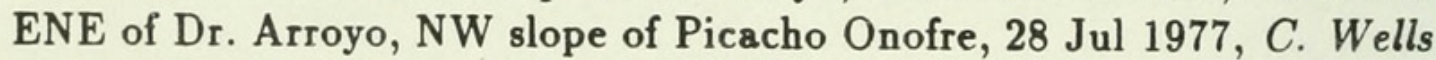
\& G. Nesom 994 (HOLOTYPE: LL!).

Sisyrinchio scabro Cham. \& Schlecht. similis sed rhizomatibus valde evolutis, floribus paucioribus in quaque spatha, tepalis majoribus, et tubo staminali longiore differt.

Perennials from a short $(5-20 \mathrm{~mm})$ rhizome bearing fibrous roots up to 10 $\mathrm{cm}$ long, thickened but not fleshy or swollen, slightly tapering distally; herbage glabrous but the leaves and stems usually beset with minute marginal papillae to hairlike teeth. Stems 1-2 per plant, erect, 2-4 dm high, compressed and 2 winged, 2-3 mm wide, slightly bent at the nodes, with 1-2 branch nodes on the upper $1 / 2-1 / 3$, each node with a leaflike bract and a terminal branch plus 1-2 axillary branches, all branches of equal to subequal length, each bearing a spathe at the apex. Leaves linear, becoming linear-lanceolate near the stem apex, $2-3 \mathrm{~mm}$ wide, the basal $7-20 \mathrm{~cm}$ long, the cauline (nodal bracts) like the basal but smaller, $5-10 \mathrm{~cm}$ long, leaves absent below the nodes. Spathes 1-2(-4) flowered, compressed, narrowly lanceolate-elliptic in outline, $18-25 \mathrm{~mm}$ long, 2.5-3.0 $\mathrm{mm}$ wide, the bracts ovate, equal to subequal, smooth margined, the outer bract fused $3-6 \mathrm{~mm}$ above the base, commonly with a broad hyaline 
margin near the base; pedicels erect to slightly spreading in flower and fruit, about the same length as the spathe. Ovary obpyriform, minutely pilose with delicate, glandular hairs; tepals blue to bluish purple, obovate-elliptic, 15-18 $\mathrm{mm}$ long, apically rounded to slightly retuse, with an aristate extension up to $1.5 \mathrm{~mm}$ long; filaments completely united into a filament tube $6-7 \mathrm{~mm}$ long, anthers erect, verticillate and essentially sessile at the summit of the column, 0.8-1.0 mm long, the style branches not or scarcely projecting beyond the tips of the anthers. Fruits ca. $4 \mathrm{~mm}$ long, 4-5 mm wide, blocky-globose, truncate at the apex, 3 angled and weakly 3 sulcate; seeds black, obscurely pitted, ca. $1 \mathrm{~mm}$ in diameter, with a large depression on one side.

Additional collections examined: MEXICO. Coahuila: Mpio. Arteaga, Las Vigas, Cañon de la Carbonera, Sierra de Arteaga, woods of pine, Douglas fir, fir, oak, and Ceanothus, 2100-2600 m, 15 Sep 1988, Villarreal et al. 4574 (ASU). Nuevo León: Mpios. Dr. Arroyo and Zaragoza, Peña Nevada area: W side of Picacho Onofre, $3230 \mathrm{~m}, 4 \mathrm{Jul}$ 1959, Beaman 2692 (TEX); Puerto Mesa del Charco, $3100 \mathrm{~m}$, glade in pine-fir forest, $25 \mathrm{Jun}$ 1978, Hinton et al. 17968 (TEX); NW slope of Picacho Onofre, 30 Jul 1977, Wells \& Nesom 448 (LL). Mpio. Galeana, Cerro Potosí: SE side, above Ejido 18 Marzo, open pine forest, ca. $3020 \mathrm{~m}, 25$ Jun 1960, Beaman 9915 (TEX); lower slopes, pine woods, 6$8000 \mathrm{ft}, 27$ Aug 1987, Bogler \& Atkins 209 (TEX); 8 mi up from 18 de Marzo, pine-oak transition, 24 Aug 1984, Lavin 4815 (TEX); near microwave tower, $9000 \mathrm{ft}, 7 \mathrm{Jul} \mathrm{1963,} \mathrm{McGregor} \mathrm{et} \mathrm{al.} 259$ (LL); clearing in pine forest, $3250 \mathrm{~m}, 8$ Aug 1970, Hinton et al. 17298 (TEX); NE face, oak forest, ca. $2800 \mathrm{~m}, 24 \mathrm{Jul}$ 1977, Wells \& Nesom 226 (LL): Cerro Potosí area, Mpio. Galeana: San José Las Joyas (N slope of CP), open pine forest, $2730 \mathrm{~m}, 28$ Aug 1983, Hinton et al. 18584 (TEX); ascent to Sierra Infernillo, ca. $15 \mathrm{mi} \mathrm{SW}$ of Galeana, 9-10000 $\mathrm{ft}$, pine savanna, 16 Jun 1934, Mueller 833 (TEX).

Sisyrinchium novoleonense is clearly a member of subg. Sisyrinchium in its blue tepals and sessile stamens borne at the apex of a filament tube. Specimens of the new species have accumulated at LL,TEX under the name of $S$. quadrangulatum Klatt, which is superficially similar in habit, but the latter is a species restricted to central México in the high mountains from Pico de Orizaba (the type locality) in Veracruz and Puebla to Nevado de Toluca in Edo. México (see Rzedowski \& Rzedowski 1985). There has been some confusion about the identity of $S$. quadrangulatum (based on variability in dried flower color, Greenman 1903), but as identified and treated by Calderón \& Rzedowski (1990), it is a member of subg. Echthronema and not at all related to $S$. novoleonense.

Sisyrinchium novoleonense occurs in the areas of Peña Nevada and Cerro Potosí of Nuevo León, and in the Sierra Arteaga of Coahuila, where it occurs mostly at elevations of 2600-3250 meters. It is known from only one collection in Coahuila (slightly north of Cerro Potosí), but it should be expected to occur more abundantly there, as do many other species with a similar pattern 
of geographic distribution.

Based on records of specimens in LL,TEX, ca. 11 species of Sisyrinchium (acknowledging the caveats below regarding taxonomic difficulties within the $S$. scabrum Schlecht. \& Cham. group) in two subgenera are known to occur in the northeastern Mexican states of Coahuila, Nuevo León, and Tamaulipas. In subg. Sisyrinchium are the following: $S$. novoleonense, the $S$. scabrum group ( $S$. scabrum, $S$. dimorphum R. Oliver, and $S$. demissum E. Greene), $S$. micranthum Cav., and $S$. biforme Bickn. Sisyrinchium biforme is a species known from coastal sites in Texas and Tamaulipas, not approaching the more montane habitats of the others. Five species of subg. Echthronema that occur in Coahuila, Nuevo León, and Tamaulipas are discussed in a separate paper (Nesom in prep.).

Among Mexican and Texan species of subg. Sisyrinchium, the new species is similar to $S$. scabrum in its branched stems, distinctively scabrous leaf and stem margins, and minutely pubescent ovaries. It differs from all other Mexican and Texan plants of subg. Sisyrinchium particularly in its large flowers (tepals) and long filament tube. It also differs from $S$. scabrum in its fewer flowers per spathe (mostly $1-2$ vs. mostly $2-6$ ). In these features, and with its localized geographic distribution and distinctive habitats, it can be identified without equivocation.

Sisyrinchium scabrum has not been recorded for Texas, but Oliver (1970) noted that $S$. ensigerum Bickn. (the type from Bexar Co., Texas) shows similarities to it in trans-Pecos Texas, and the two probably are conspecific. Both also are similar to $S$. dimorphum (the type from Valverde Co., Texas), which Oliver (1970) distinguished from $S$. ensigerum in its relatively longer stems, spreading-deflexing pedicels shorter than the spathes at anthesis, and its olivaceous color when dried; also, the ovaries of $S$. dimorphum are glabrous, compared to the minutely hairy ones of $S$. scabrum and other close relatives. Plants of both species are very similar in vegetative and floral morphology, lacking well developed rhizomes and with tepals mostly $7-9 \mathrm{~mm}$ long and a filament tube 2-3(-4) $\mathrm{mm}$ long. Although $S$. dimorphum is primarily endemic to the Edwards Plateau of Texas, it is also known from a few scattered localities in northern Coahuila, Nuevo León, and Tamaulipas. Plants in Chiapas and Guatemala identified as $S$. dimorphum (Henrich \& Goldblatt 1987) are more similar in both habit and habitat to $S$. biforme Bickn. and are better identified as the latter, although this needs further investigation. Sisyrinchium scabrum is widely distributed in México, from Oaxaca to Veracruz, Nuevo León, and Coahuila and to Jalisco and Chihuahua in the western part of the country. The latter is abundant in Nuevo León where it occurs at relatively low elevations (ca. $1500-2700 \mathrm{~m}$ ) compared to $S$. novoleonense. There are numerous specimens in LL,TEX of $S$. scabrum collected from the foothills of both Peña Nevada and Cerro Potosí.

Sisyrinchium micranthum Cav., another species of subg. Sisyrinchium pe- 
ripherally related to $S$. scabrum, is known from a few collections in southcentral Nuevo León at the northern limit of its distribution, extending from there southward through San Luis Potosí and Veracruz into Central and South America. It sometimes may appear similar to $S$. scabrum, but plants of $S$. micranthum are annual, without any rhizome, and they generally produce shorter stems with 0-1 branches, reflexing pedicels, mostly glabrous ovaries, and smaller spathes, tepals, anthers, and capsules.

Also closely related to Sisyrinchium scabrum is what can be identified in northern Coahuila as $S$. demissum (the type from Arizona). It differs from $S$. scabrum and $S$. dimorphum in its more strongly developed rhizome and erect pedicels that conspicuously exceed the spathe. Sisyrinchium demissum, however, produces flowers in the same size range of $S$. scabrum and $S$. dimorphum and appears to intergrade with $S$. scabrum. Further northwest, formal varieties have been recognized within $S$. demissum (Kearney \& Peebles 1960), which appears to intergrade with yet other species (Holmgren 1977; Cholewa \& Henderson 1984). A more detailed study is needed of the $S$. scabrum group, particularly in northern México and the southcentral United States, before an accurate accounting can be given of the variation patterns and corresponding nomenclature.

\section{ACKNOWLEDGMENTS}

We thank Billie Turner and Carol Todzia for their review of the manuscript and the staff of ASU for a loan of specimens.

\section{LITERATURE CITED}

Calderón de Rzedowski, G. \& J. Rzedowski. 1985. Sisyrinchium conzattii (Iridaceae), una nueva especie de las altas montanas del centro de Mexico. Phytologia 58:371-376.

1990. Iridaceae. Pp. 323-340 in Flora Fanerogamica del Valle de México. Vol. III. Monocotyledoneae. Inst. Ecología, Pátzcuaro, Michoacán, México.

Cholewa, A.F. \& D.M. Henderson. 1984. Biosystematics of Sisyrinchium section Bermudiana (Iridaceae) of the Rocky Mountains. Brittonia 36:342363 .

Goldblatt, P. 1990. Phylogeny and classification of Iridaceae. Ann. Missouri Bot. Gard. 77:607-627. 
Goldblatt, P., J.E. Henrich, \& R.C. Keating. 1989. Seed morphology of Sisyrinchium (Iridaceae - Sisyrinchieae) and its allies. Ann. Missouri Bot. Gard. 76:1109-1117.

Goldblatt, P., P. Rudall, \& J.E. Henrich. 1990. The genera of the Sisyrinchium alliance (Iridaceae: Iridoideae): phylogeny and relationships. Syst. Bot. 15:497-510.

Greenman, J. 1903. New and otherwise noteworthy angiosperms from México and Central America. Proc. Amer. Acad. Arts 39:69-120.

Henrich, J.E. \& P. Goldblatt. 1987. Mesoamerican Sisyrinchium (Iridaceae): New species and records and notes on typification. Ann. Missouri Bot. Gard. 74:903-910.

Holmgren, P.K. 1977. Sisyrinchium. Intermountain Fl. 6:538-543.

Kearney, T.H. \& R.H. Peebles. 1960. Arizona Flora (ed. 2). University of California Press, Berkeley, California.

McVaugh, R. 1989. Sisyrinchium. Flora Novo-Galiciana 15:311-330.

Nesom, G.L. In prep. New species of Sisyrinchium subg. Echthronema (Iridaceae) from northern Mexico.

Oliver, R.L. 1969. Sisyrinchium dimorphum (Iridaceae), a new species from Texas and Mexico. Ann. Missouri Bot. Gard. 55:397.

1970. Sisyrinchium. Pp. 425-428 in Correll, D.S. \& M.C. Johnston, Manual of the Vascular Plants of Texas. Texas Research Foundation, Renner, Texas.

Rudall, P., A.Y. Kenton, \& T.J. Lawrence. 1986. An anatomical and chromosomal investigation of Sisyrinchium and allied genera. Bot. Gaz. 147:466-477. 


\section{$2 \mathrm{BHL}$ Biodiversity Heritage Library}

Nesom, G L. 1992. "A new species of Sisyrinchium subg. Sisyrinchium (Iridaceae) from Mexico." Phytologia 73, 429-434.

https://doi.org/10.5962/bhl.part.16723.

View This Item Online: https://www.biodiversitylibrary.org/item/46862

DOI: https://doi.org/10.5962/bhl.part.16723

Permalink: https://www.biodiversitylibrary.org/partpdf/16723

\section{Holding Institution}

New York Botanical Garden, LuEsther T. Mertz Library

\section{Sponsored by}

The LuEsther T Mertz Library, the New York Botanical Garden

\section{Copyright \& Reuse}

Copyright Status: In copyright. Digitized with the permission of the rights holder.

Rights Holder: Phytologia

License: http://creativecommons.org/licenses/by-nc-sa/3.0/

Rights: https://biodiversitylibrary.org/permissions

This document was created from content at the Biodiversity Heritage Library, the world's largest open access digital library for biodiversity literature and archives. Visit BHL at https://www.biodiversitylibrary.org. 